\title{
Contributions to the knowledge of lice diversity (Phthiraptera: Amblycera and Ischnocera) in birds from Peru
}

\author{
Fabiola PRÍNCIPE ${ }^{1}$, David MINAYA ${ }^{1}$, Senior CIPRIANO ${ }^{2}$, Azucena NAUPAY ${ }^{3}$ \\ \& José IANNACONE ${ }^{1,4}$
}

\begin{abstract}
${ }^{1}$ Laboratorio de Ecología y Biodiversidad Animal. Facultad de Ciencias Naturales y Matemática. Grupo de Investigación en Sostenibilidad Ambiental (GISA), Escuela Universitaria de Posgrado. Universidad Nacional Federico Villarreal. El Agustino, Lima 15007, Perú. ${ }^{2}$ Facultad de Medicina Veterinaria y Zootecnia. Universidad Nacional Hermilio Valdizán. Huánuco 10003, Perú. ${ }^{3}$ Laboratorio de Parasitología Humana y Animal. Facultad de Ciencias Biológicas. Universidad Nacional Mayor de San Marcos. Breña, Lima 15081, Perú. ${ }^{4}$ Carrera de Ciencias Ambientales. Universidad Científica del Sur. Villa el Salvador, Lima 15067, Perú, e-mail: joseiannacone@gmail.com
\end{abstract}

\begin{abstract}
Peru has a great diversity of birds, having more than 1870 species in its territory. However, studies on chewing lice (Phthiraptera) in birds from Peru are still limited. The objective of this study is to contribute to the knowledge of the diversity of lice in birds of Peru. The material used comes from the Zoological Collection of the Natural History Museum of the Universidad Nacional Federico Villarreal, Lima, Peru. Ten species of lice distributed in three families were identified: three species of the Menoponidae family, five species of Philopteridae and two species of Ricinidae collected from seven species of birds. This work records for the first time Hohorstiella lata Piaget, 1880, Quadraceps eugrammicus (Burmeister, 1838), Trochiloecetes illumani Carriker, 1960 and Ricinus frenatus Burmeister, 1838 in Peru; likewise, four new hosts of the order Passeriformes are registered for Mayriphilopterus ernsti Mey, 2004, Threnetes leucurus (Linnaeus, 1766) as a new host for T. illumani and two new hosts for $R$. frenatus; Larus belcheri Vigors, 1829 is also reported as a new host for Quadraceps eugrammicus (Burmeister, 1838) and Austromenopon transversum Denny, 1842.
\end{abstract}

Key words: Columbiformes, Ectoparasites, Entomology, Parasitology, Passeriformes

Resumen: Aportes al conocimiento de la diversidad de piojos (Phthiraptera: Amblycera e Ischnocera) en aves del Perú. El Perú presenta una gran diversidad de aves, teniendo más de 1870 especies en su territorio. Sin embargo, los estudios sobre malófagos (Phthiraptera) en aves del Perú son aún limitados. El presente estudio tiene por objetivo aportar al conocimiento de la diversidad de piojos en aves del Perú. El material utilizado proviene de la Colección Zoológica del Museo de Historia Natural de la Universidad Nacional Federico Villarreal, Lima, Perú. Fueron identificadas diez especies de piojos distribuidas en tres familias: tres especies de la familia Menoponidae, cinco especies de Philopteridae y dos especies de Ricinidae colectadas de siete especies de aves. Este trabajo registra por primera vez a Hohorstiella lata Piaget, 1880, Quadraceps eugrammicus (Burmeister, 1838), Trochiloecetes illumani Carriker, 1960 y Ricinus frenatus Burmeister, 1838 en el Perú; así mismo se registran cuatro nuevos hospederos del orden Passeriformes para Mayriphilopterus ernsti Mey, 2004, Threnetes leucurus (Linnaeus, 1766) como nuevo hospedero para T. illumani y dos nuevos hospederos para R. frenatus; también se reporta a Larus belcheri Vigors, 1829 como nuevo hospedero para Quadraceps eugrammicus (Burmeister, 1838) y Austromenopon transversum Denny, 1842.

Palabras clave: Columbiformes, Ectoparásitos, Entomología, Parasitología, Passeriformes

\section{INTRODUCTION}

Research on ectoparasites in birds involving lice, mites, fleas, ticks, and flies has been intensifying in recent years (McAllister et al., 2018; Hasan, 2019). The importance of the studies of ectoparasites of birds includes different aspects among which the influence that they have on their hosts stands out, as well as the conditioning that can cause the parasitic load in the behavior, feeding, reproduction and migration of the birds (Clayton et al., 2010; Hicks et al., 2018).

Chewing lice (Amblycera and Ischnocera) belonging to the order Phthiraptera are obligate and specific ectoparasites of birds and mammals (Parra-Henao et al., 2011; Gomez-Puerta 
\& Cribillero, 2015). Lice can be highly specific to their hosts, as several species have been identified in a single host; while some species of lice have been recorded in other closely related birds (Tavera et al., 2019). For example, lice of the genus Acidoproctus Piaget, 1878, are the most common in wild birds, having a predilection for the families Anatidae and Anseranatidae (Arnold, 2006). In the same way, it is mentioned that lice of the genera Austromenopon Bedford 1939, Quadraceps Clay and Meinertzhagen, 1939, Saemundssonia Timmermann, 1936 and Ciconiphilus Bedford, 1939, are closely associated with birds of the order Charadriiformes (Figueiredo et al., 2010; Tavera et al., 2019).

The importance of the study of chewing lice in birds contemplates two points of view, which the phylogenetic that encompasses common parasites in different hosts, which confers close kinship relationships (Saavedra-Orjuela et $a l ., 2014)$, and the pathological one since many lice act as biological and mechanical vectors of pathogens such as rickettsia, and the direct damage they cause due to their eating and fixation behavior in different parts of the body (ParraHenao et al., 2011).

In Peru, studies of lice in birds have been addressed in recent years with the work of several researchers (Gomez-Puerta \& Lujan 2018; SotoPatiño et al., 2018; Tavera et al., 2019, among others), who recorded new hosts and geographic range extensions for many species of lice. Despite this, there is still a significant fraction of birds that do not present any study on ectoparasites in various regions of Peru; the present study aims to contribute to the knowledge of the diversity of lice in birds from Peru.

\section{MATERIAL AND METHODS}

The specimens studied were taken from the collection of Helminths Parasites and Related Invertebrates (HPIA-ZOO) from the Zoological Collection of the Museum of Natural History of the National University Federico Villarreal (MUFV). Hosts, locations, harvest dates and collectors are mentioned in the results section.

The morphologic study of the specimens followed the methodology proposed by Palma (1978), which consisted of rinsing the specimens in a $20 \%$ Potassium hydroxide $(\mathrm{KOH})$ solution for $12 \mathrm{~h}$. Then the samples were kept in distilled water for $1 \mathrm{~h}$, they were dehydrated in successive series of ethanol $(50 \%, 70 \%, 90 \%$ and $100 \%), 30$ min in each solution, subsequently diaphanized in Eugenol for $24 \mathrm{~h}$. Finally, the samples were mounted in Balsam of Canada. The specimens were dried at $50-60{ }^{\circ} \mathrm{C}$ in an oven, for three weeks (Tavera et al., 2019).

For the morphological description of the specimens, photographs and measurements were taken using a Euromex ${ }^{\circledR}$ light microscope with ImageFocus Spanish version4 software. Measurements are shown in micrometers $(\mu \mathrm{m})$ unless otherwise indicated in the text. For the taxonomic identification of lice, specialized keys were followed (Timmermann, 1952; Eichler, 1953; Clay, 1959; Carriker, 1960; Nelson, 1972; Price et al., 2003; Mey, 2004; Valim \& Linardi, 2007; Martín, 2009; Naz et al., 2012). The host nomenclature follows Schulenberg et al. (2010).

The procedures for collecting parasitic fauna in the birds was approved by resolution 2558-2018-CU-UNFV that includes the code of ethics for research at the Universidad Nacional Federico Villarreal (UNFV) and by Director's Resolution $\mathrm{N}^{\circ}$ 024-2014-SERFOR-DGGSPFFS. For the management of the parasitic fauna, the guidelines of the protection and animal welfare law of Peru were followed (Law No. 30407: Article 19). The collection of the parasitic fauna is indicated by the SERFOR (Servicio Nacional Forestal y de Fauna Silvestre) of Peru that establishes the guidelines for the scientific investigation of flora and/or wild fauna (Resolution of Executive Direction №660-2016 SERFOR-DE).

\section{RESULTS}

Lice species were collected from seven bird species: belcher's gull Larus belcheri Vigors, 1829, pale-tailed barbthroat Threnetes leucurus (Linnaeus, 1766), rufous-rumped foliage-gleaner Philydor erythrocercum (Pelzeln, 1859), grey-breasted flycatcher Lathrotriccus griseipectus (Lawrence, 1869), Common scale-backed antbird Willisornis poecilinotus (Cabanis, 1847), wedge-billed woodcreeper Glyphorynchus spirurus (Vieillot, 1819) and rock dove Columba livia (Gmelin, 1789).

Ten lice species distributed in three families are described: three species of the Menoponidae family, five species of Philopteridae and two species of Ricinidae.

Amblycera

Menoponidae Mjöberg, 1910

Austromenopon Bedford, 1939

Austromenopon transversum (Denny, 1842)

(Fig. 1A -D) 

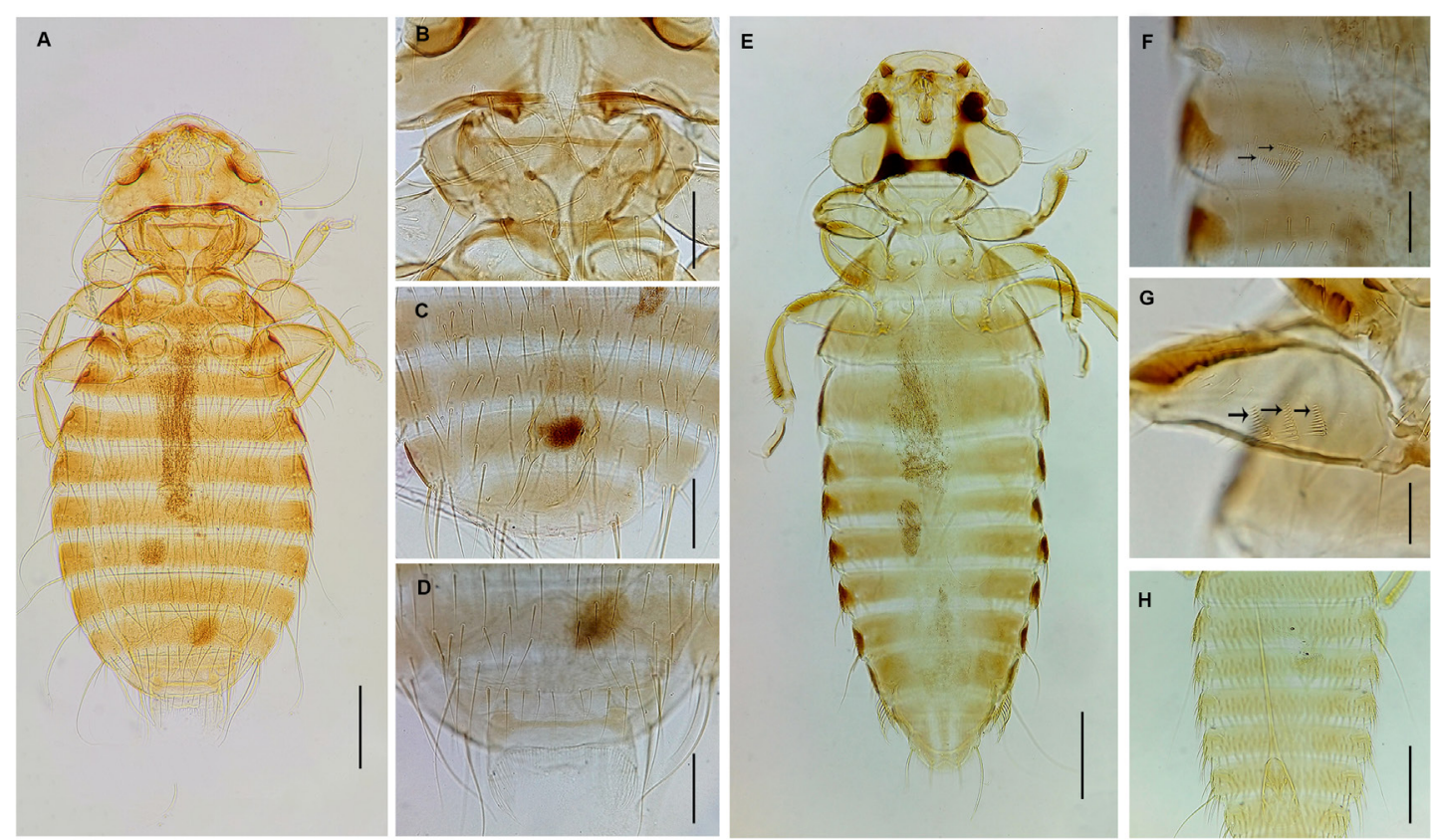

Fig. 1. A-D. Austromenopon transversum, A. Whole body (female), dorsal view $(200 \mu \mathrm{m})$, B. Lunar form of the prothorax $(100 \mu \mathrm{m})$, C. Male reproductive system $(50 \mu \mathrm{m})$, D. Vulvar segment of female with presence of short mushrooms like structures $(50 \mu \mathrm{m})$. E-H. Colpocephalum turbiratum, E. Whole body (female), dorsal view (200 $\mu \mathrm{m}), \mathrm{F}$. Two rows of short mushrooms in the ventral area of the abdominal sternite III (arrows) $(50 \mu \mathrm{m}), \mathrm{G}$. Three rows of short mushrooms on the femur of the third pair of legs (Arrows) $(50 \mu \mathrm{m}), \mathrm{H}$. Male reproductive system $(200 \mu \mathrm{m})$.

Material studied: MUFV: ZOO-HPIA:161.

Host: Larus belcheri, Peru: Lima: Ventanilla, $11^{\circ} 52^{\prime} 15^{\prime \prime}$ S, $77^{\circ} 9^{\prime} 30^{\prime \prime}$ W, 21-23.ix.2017, Naupay A.

Description: Based on 4 individuals (1 male, 3 female). Prothorax in the lunar form, prothoracic marginal setae do not reach the metathorax, long prothoracic dorsal setae (males), a lateral long seta, starting from the second segment of the abdomen; margin of the subgenital plate in the female is transverse and presents short setae. Male: Total body length $1194(\mathrm{n}=1)$; head length 237; length of prothorax 158, length of pterothorax 245; abdomen length 543, abdomen width 497. Female: Total body length 1665 (1642-1677, $\mathrm{n}=3)$; head length 251 (232-264), head width 506 (498 - 513); prothorax length 217 (197-229), pterothorax length 273 (267 -279); abdomen length 966 (926-1024), abdomen width 719 (685 - 748).

Comment: Austromenopon transversum was first reported in Peru parasitizing Larus modestus Tschudi, 1843 (Dale, 1970) and in Chile it is reported in hosts of the family Laridae (González-Acuña et al., 2006), but not including L. belcheri. Likewise, Price et al. (2003) and Smith et al. (2020) have reported A. tranversum in different species of the genus Larus but not in $L$. belcheri, so this would be the first report of $A$. transversum parasitizing $L$. belcheri.

Colpocephalum Nitzsch, 1818

Colpocephalum turbinatum Denny, 1842 (Fig. 1E-H)

Material studied: MUFV: ZOO-HPIA:157.

Host: Columba livia, Peru: Lima: Cercado de Lima, $12^{\circ} 2^{\prime} 43^{\prime \prime}$ S, $77^{\circ} 1^{\prime} 45^{\prime \prime} \mathrm{W}, 02-03 . i x .2017$, Naupay, A.

Description: Based on 7 individuals (4 males, 3 females). The species is characterized by presenting two rows of short setae in the ventral part of the abdominal sternum III and three rows of short spiny setae in the ventral part of the III femur. Females have a "W" shaped anal plate. Male: Total body length 1542(1431 -1797, $\mathrm{n}=4)$; head length 270 (243 -287), head width 440 (424-469); prothorax length 142 (115-167), pterothorax length 259 (132 -363); abdomen length 871 (797 -985), abdomen width 476 (426 -585). Female: Total body length 1741 (1713 $-1762, \mathrm{n}=3)$; head length $283(266-294)$, head width 459 (447-467); prothorax length 157 (152 -159), pterothorax length 266 (233 -286); abdo- 
men length 1057 (974 -1100), abdomen width 580 (552 - 617).

Comment: Colpocephalum turbinatum is considered a generalist species since it has been reported parasitizing different orders of birds, such as Columbiformes, Falconiformes, Accipitriformes, Ciconiformes and Galliformes by various authors in different countries (Martín, 2006; ParraHenao et al., 2011; Adly et al., 2019). This species has been recorded for the first time in Peru in the study of Dale (1970) parasitizing C. livia, this relationship coincides with our study where the association is also observed.

\section{Hohorstiella Eichler, 1940 \\ Hohorstiella lata (Piaget, 1880)}

(Fig. 2A -D)

Material studied: MUFV: ZOO-HPIA:158.

Host: Columba livia, Peru: Lima: Cercado de Lima, $12^{\circ} 2^{\prime} 43^{\prime \prime}$ S, $77^{\circ} 1^{\prime} 45^{\prime}$ W, 02-03.ix.2017, Naupay, A.

Description: Based on three adult females. Head wider than long, with a pair of spines on the ventral part, abdomen oblong, antenna of two segments, the first segment with a marked lobe and the second small and rounded, abdominal sternite IV-V with thin brush-shaped seta; broad vulvar margin with long and short fine mushrooms like structures. Total body length 2048 (2051 -2454, n = 3); head length 393 (366 $-417)$, head width 670 (662 -675); length of the prothorax 227 (209-256), length of the pterothorax 386 (330 -417); abdomen length 1258 (1115 -1371), abdomen width 1151 (1079-1235).

Comment: The association of Columba livia and Hohorstiella lata found in this study coincides with that reported by Quiguango (2015) in Ecuador, by Cortés et al. (2016) in Colombia and in the same way in Brazil (Amaral et al., 2017). In Peru, H. lata has not been registered in previous works, so this study would be the first to report this ectoparasite within the diversity of chewing lice for the country.

Ricinidae Neumann, 1890

Ricinus De Geer, 1778

Ricinus frenatus Burmeister, 1838 (Fig. 2E-2H)

Material studied: MUFV: ZOO-HPIA:151 and (MUFV: ZOO-HPIA:152.

Hosts: Philydor erythrocercum, Peru: Huanuco: Puerto Inca 9 $36^{\prime} 49.32$ 'S, $74^{\circ} 56^{\prime} 8.16^{\prime}$ W, 18-22. iii.2018, Cipriano, S.; Lathrotriccus griseipec- tus, Peru: Huanuco: Puerto Inca 9'36'49's, 745'''W, 18-22.iii.2018. Cipriano, S.

Description: Based on 3 individuals (females). Head convex in shape. This species differs from the other Ricinus species by presenting the end of the mandibular lobes (left and right) of similar size, slightly ovoid sclerites, labium with 14 pairs of setae, seta a1 as long as the pa series. Total body length 4500 (4462 - 4552, n = 3); head length 977 (971-986), head width 762 (754-767); prothorax length 477 (467 - 492), pterothorax length 632 (556 - 689); abdomen length 2414 (2378 - 2443), abdomen width 1193 (1171 - 1214). Comment: The genus Ricinus has been reported in the study by Soto-Patiño et al. (2018) parasitizing species from different families of the order Passeriformes found in Peru. In this study we report for the first time $R$. frenatus in Peru and two new hosts: P. erythrocercum and L. griseipectus.

Trochiloecetes Paine \& Mann, 1913

Trochiloecetes illumani Carriker, 1960 (Fig. 3A -D)

Material studied: MUFV: ZOO-HPIA:153.

Host: Threnetes leucurus, Peru: Huanuco: Puerto Inca $9^{\circ} 36^{\prime} 49^{\prime \prime}$ S, 7456' $8^{\circ}$ W, 18-22. iii.2018, Cipriano, S.

Description: Based on 5 individuals (1 male, 4 female). Short and wide head, concave fronts (430). It has a thin transverse frontal carina and is made up of two narrow bands across the occipital region, thinner prothorax and pterothorax carina, slightly thickened longer jaws, very thick lateral carina and abdominal joints. Male: Total body length $(2059, \mathrm{n}=1)$; head length 500 , head width 609; prothorax length 302, pterothorax length 300; abdomen length 957, abdomen width 1047. Female: Total body length 2372 (2209 2455, $\mathrm{n}=4$ ); head length 528 (501 - 556), head width 650 (647 - 652); prothorax length 337 (326 - 350), pterothorax length 338 (248 -390); abdomen length 1172 (1063 - 1246), abdomen width 1095 (1006 - 1145).

Comment: The genus Trochiloecetes has been reported parasitizing different species of birds of the Trochilidae family in Brazil (Roda \& Farias, 1999), Argentina (Abrahamovich et al., 2006) and in Peru by Soto-Patiño et al. (2018). Additionally, Carriker (1960) reported the genus for the first time in Peru in the host Threnetes leucurus, the latter association coincides with our study. Therefore T. illumani is reported as a new ectoparasite for Peru, and the Bardud Hermit (T. leucurus) as a new host for this species. 

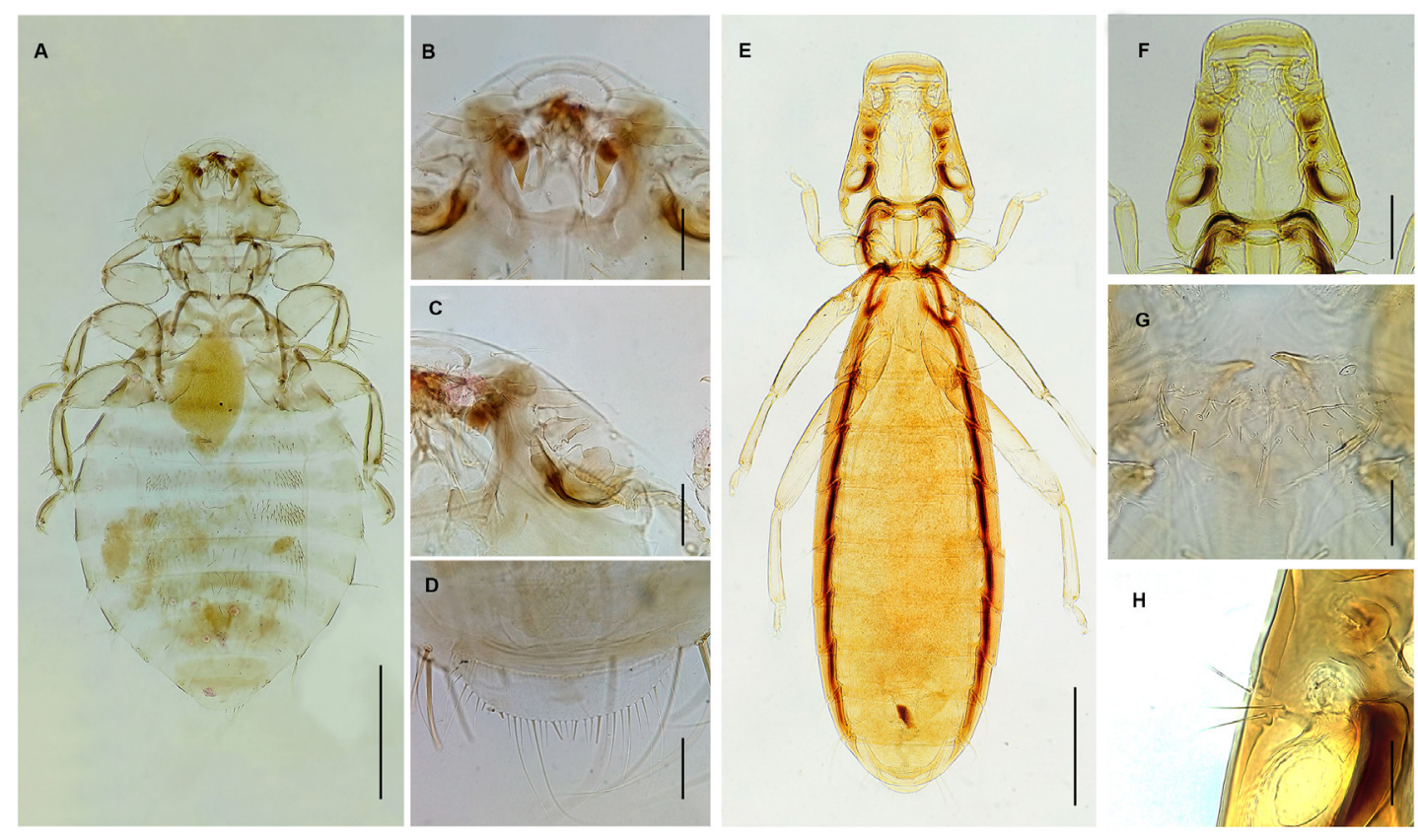

Fig. 2. A-D. Hohorstiella lata, A. Whole body (female) $(500 \mu \mathrm{m})$. B. Pair of spines on the ventral head $(100 \mu \mathrm{m})$, C. Two-segment antenna, the first segment with a marked lobe $(50 \mu \mathrm{m})$, D. Vulvar segment of female with long and short mushrooms like structures $(50 \mu \mathrm{m})$. E-H. Ricinus frenatus, E. Whole body (female) $(500 \mu \mathrm{m}), \mathrm{F}$. Convex head shape $(200 \mu \mathrm{m})$, G. Labium with 14 pairs of mushrooms and jaw lobes of almost equal sizes $(20 \mu \mathrm{m}), \mathrm{H}$. Seta a1 as long as the "pa" series $(20 \mu \mathrm{m})$.

\section{Ischnocera \\ Philopteridae Burmeister, 1838 \\ Campanulotes Kéler, 1939 \\ Campanulotes compar (Burmeister, 1838)}

(Fig. 3E-H)

Material studied: MUFV: ZOO-HPIA:156.

Host: Columba livia, Peru: Lima: Cercado de Lima, $12^{\circ} 2^{\prime} 43^{\prime \prime} \mathrm{S}, 77^{\circ} 1^{\prime} 45^{\prime \prime} \mathrm{W}, 02-03 . i x .2017$, Naupay, A.

Description: Based on 6 individuals (3 males, 2 females). Antenna with four segments, the first segment, longer than the others. Acute temples, IX male abdominal segment presents a slightly bilobed plate provided with setae at each lobar end and a pair of contiguous lateral sclerites. Vulvar margin (female) bordered by rows of tiny mushroom like structures. Rounded clipeal border and slightly elongated pre-antennal region. Male: Total body length 1123 (1078 -1156, n $=3$ ); head length 353 (343 -359), head width 366 (354-376); prothorax length 108 (86-133), pterothorax length 158 (136-176); abdomen length 497 (474-519), abdomen width 555 (477 -680). Female: Total body length 1376 (1365 -1387, $\mathrm{n}=2)$; head length 398 (397 -399), head width 401 (393-409); prothorax length 119 (109
- 128), pterothorax length 200 (186 -214); abdomen length 609 (479-697), abdomen width 512 (438-558).

Comment: Campanulotes compar is an ectoparasite that has been reported in Gallus gallus domesticus in Brazil (Ferreira et al., 2013) and in columbiform birds such as the common dove C. livia in Chile by González et al. (2004), in the same way in Ecuador by Quiguango (2015), the same relationship was reported by Dale (1970) for the first time in Peru, thus coinciding with our study.

Columbicola Ewing, 1929

Columbicola columbae (Linnaeus, 1758)

(Fig. 4A -D)

Material studied: MUFV: ZOO-HPIA:159.

Host: Columba livia, Peru: Lima: Cercado de Lima, $12^{\circ} 2^{\prime} 43^{\prime \prime} \mathrm{S}, 77^{\circ} 1^{\prime} 45^{\prime \prime} \mathrm{W}, 02-03.1 x .2017$, Naupay, A.

Description: Based on 7 individuals (5 males, 2 females). The species of this genus are characterized by having an elongated and thin body. Likewise, they present a clear sexual dimorphism based on the antennas, the males present the third segment of the antenna (proximal seg- 

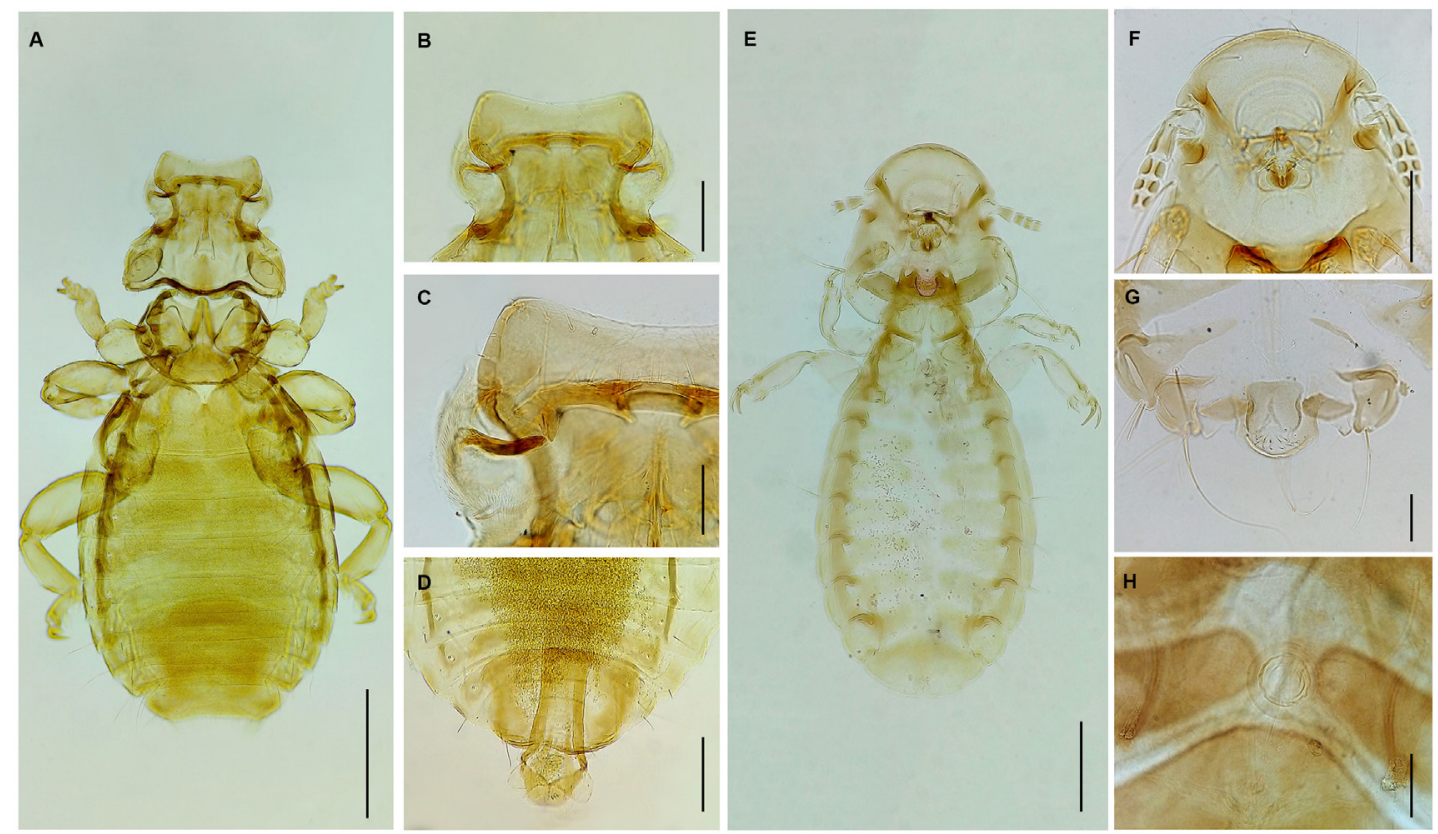

Fig. 3. A-D. Trochiloecetes illumani, A. Whole body (female), dorsal view $(500 \mu \mathrm{m})$, B. Concave fronts $(200 \mu \mathrm{m})$, C. Two-band thin cross front carina $(100 \mu \mathrm{m})$, D. Male reproductive system $(200 \mu \mathrm{m})$. E-H. Campanulotes compar, E. Whole body (female) $(200 \mu \mathrm{m}), \mathrm{F}$. Antenna in 4 segments, the first segment, longer $(100 \mu \mathrm{m}), \mathrm{G}$. Male reproductive apparatus in two lobes, provided with short mushrooms at each end $(100 \mu \mathrm{m}), \mathrm{H}$. Female genital pore $(50 \mu \mathrm{m})$.

ment) wider and more robust compared to the female that has it in the form of a brush and the vulvar segment of the female in two lobes (Eichler, 1953). Male: Total body length 2642 $(2409-2749, \mathrm{n}=5)$; head length $545(525-561)$, head width 274 (266 -279); prothorax length 144 (128 - 173), pterothorax length $304(271-350)$; abdomen length 1649 (1361 -1773), abdomen width 371 (350 -411). Female: Total body length 2445 (2247 - 2643, $\mathrm{n}=2$ ); head length 536 (503 - 569), head width 273 (267 - 278); prothorax length 134 (123-144), pterothorax length 279 (275-282); length of abdomen 1497 (1318 - 1676), width of abdomen 351 (331 - 371).

Comment: Columbicola columbae is a cosmopolitan ectoparasite common in pigeons, and whose specific association has been reported in Peru (Naupay et al., 2015; Castro et al., 2017), Colombia (Pérez et al., 2015), Brazil (De Oliveira et al., 2000), Chile (González et al., 2004) to name a few, thus coinciding with our results.

Mayriphilopterus Mey, 2004 Mayriphilopterus ernsti Mey, 2004 (Fig. 4E-H)

Material studied: Peru: Huanuco: Puerto Inca 9 36'49”'S, $74^{\circ} 56^{\prime} 8^{\prime}$ "W, 10-15.v.2018, Cipriano,
S. (MUFV:ZOO-HPIA:154); Peru: Huanuco: Puerto Inca 9³6'49"S, 7456'8”W, 10-15.v.2018, Cipriano, S. (MUFV:ZOO-HPIA:155); Peru: Huanuco: Puerto Inca $9^{\circ} 36^{\prime} 49^{\prime \prime} \mathrm{S}, 74^{\circ} 56^{\prime}{ }^{\prime \prime} \mathrm{W}$, 10-15.v.2018, Cipriano, S. (MUFV:ZOOHPIA:163); Peru: Huanuco: Puerto Inca 9³6'49''S, 7456'8”W, 10-15.v.2018, Cipriano, S. (MUFV:ZOO-HPIA:164).

Hosts: Philydor erythrocercum, Peru: Huanuco: Puerto Inca 9'36'49''S, 7456' '"W, 18-22.iii.2018, Cipriano, S.; Lathrotriccus griseipectus, Peru: Huanuco: Puerto Inca $9^{\circ} 36^{\prime} 49^{\prime \prime}$ S, $74^{\circ} 56^{\prime} 8^{\prime \prime} \mathrm{W}, 18$ 22.iii.2018, Cipriano, S.; Willisornis poecilinotus, Peru:Huanuco:PuertoInca 9'36'49'’S, 7456'8'W, 18-22.iii.2018, Cipriano, S.; Glyphorynchus spirurus, Peru: Huanuco: Puerto Inca 9³6'49's, 74 56 '8”, 18-22.iii.2018, Cipriano, S. Description: Based on 4 individuals (1 male, 3 female). It is characterized by the absence of a functional conus; trabecula well developed. Clypeus with hyaline membrane without marginal sclerotization. Presence of 4 pairs of spatulate mushrooms like structures in the clipped hyaline membrane, the latter being the most distinctive character. Male: Total body length 1764 $(\mathrm{n}=1)$; head length 607 , head width 597; length of prothorax 213, length of pterothorax 232; abdomen length 712, abdomen width 535. Female: 

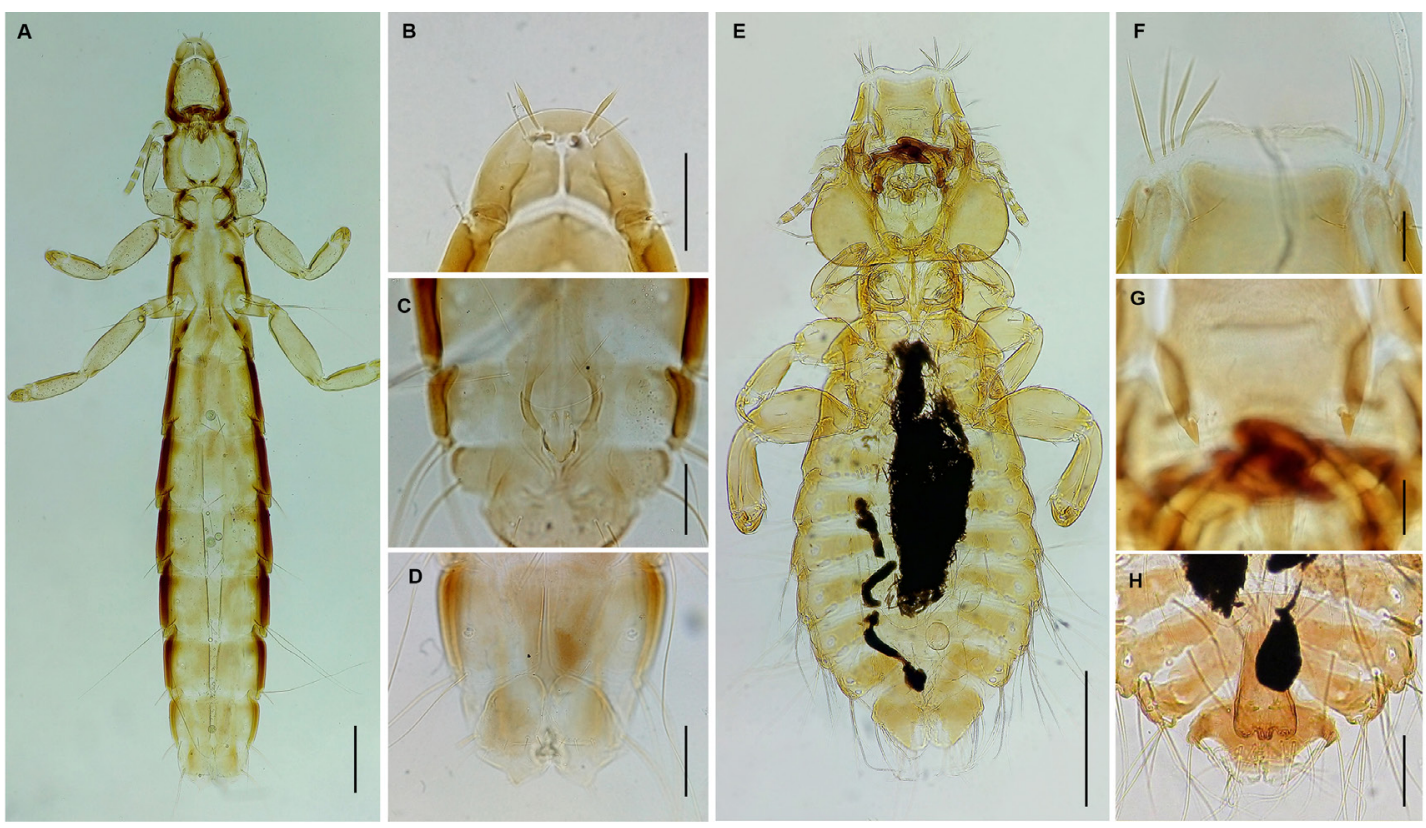

Fig. 4. A-D. Columbicola columbae A. Whole body (female) $(200 \mu \mathrm{m})$, B. Brush Mushroom (50 $\mu \mathrm{m})$, C. Male reproductive system $(100 \mu \mathrm{m})$, D. Vulvar segment of female in two lobes $(100 \mu \mathrm{m})$. E-H. Mayriphilopterus ernsti E. Whole body (female), ventral view $(400 \mu \mathrm{m})$. F. Four spatula mushrooms on each side of the fronts $(50 \mu \mathrm{m}), \mathrm{G}$. Strong thorns $(50 \mu \mathrm{m}), \mathrm{H}$. Male copulatory organ $(200 \mu \mathrm{m})$.

Total body length 2513 (2403 - 2586, $\mathrm{n}=3$ ); head length 693 (676-715), head width 704 (698710); prothorax length 272 (254-307), pterothorax length 324 (308-351); abdomen length 1224 (1165-1279), abdomen width 837 (796-883).

Comment: Mayriphilopterus ernsti was discovered and described for the first time by Mey (2004) in Monasa morphoeus peruana Sclater, 1856 in the province of Victoria, Río Pachitea, Peru. Our study expands the host list for $M$. ernsti with species of the order Passeriformes: Philydor erythrocercum, Lathrotriccus griseipectus, Willisornis poecilinotus, and Glyphorynchus spirurus.

Quadraceps Clay \& Meinertzhagen, 1939

Quadraceps eugrammicus (Burmeister, 1838)

(Fig. 5A -D)

\section{Material studied: MUFV: ZOO-HPIA:162.}

Host: Larus belcheri, Peru: Lima: Ventanilla, $11^{\circ} 52^{\prime} 15^{\prime}$ 'S, $77^{\circ} 9^{\prime} 30^{\prime \prime} \mathrm{W}, 21-23 . i x .2017$. Naupay A. Description: Based on 5 individuals (4 males, 1 female). The antennae present in the last two segments a darker coloration than the rest of the segments. The contours of the temples form an acute angle. The edge of the head has dark pigmentation, except for the frontal area. It has a long mushroom that grows from the edge of the temple. Abdominal segments have transverse dark brown spots; Dark coloration that extends to the entire proximal part of the basal plate (Timmermann, 1952). Male: Total body length 1763 (1708-1794, $\mathrm{n}=4)$; head length 505 (469-543), head width 363 (357 -367); prothorax length 129 (102-141), pterothorax length 190 (175-207); abdomen length 933 (907-974), abdomen width 421 (424-472). Female: Total body length $2907(n=1)$, head length 527, head width 365. Prothorax length 108, pterothorax length 186. Abdomen length 1176, abdomen width 460 .

Comment: The genus Quadraceps was first reported in Peru by Carriker (1950), finding the congeneric species Quadraceps burhinoides Carriker, 1950 in hosts of the family Charadriidae, from Paramonga and later by Gomez-Puerta \& Lujan-Vega (2018) in Surco, Lima. In our study, we reported for the first time on Q. eugrammicus in Peru and L. belcheri as a new host for this species.

Saemundssonia Timmermann, 1936 Saemundssonia (Saemundssonia) lari (O. Fabricius, 1780)

(Fig. 5E-H) 

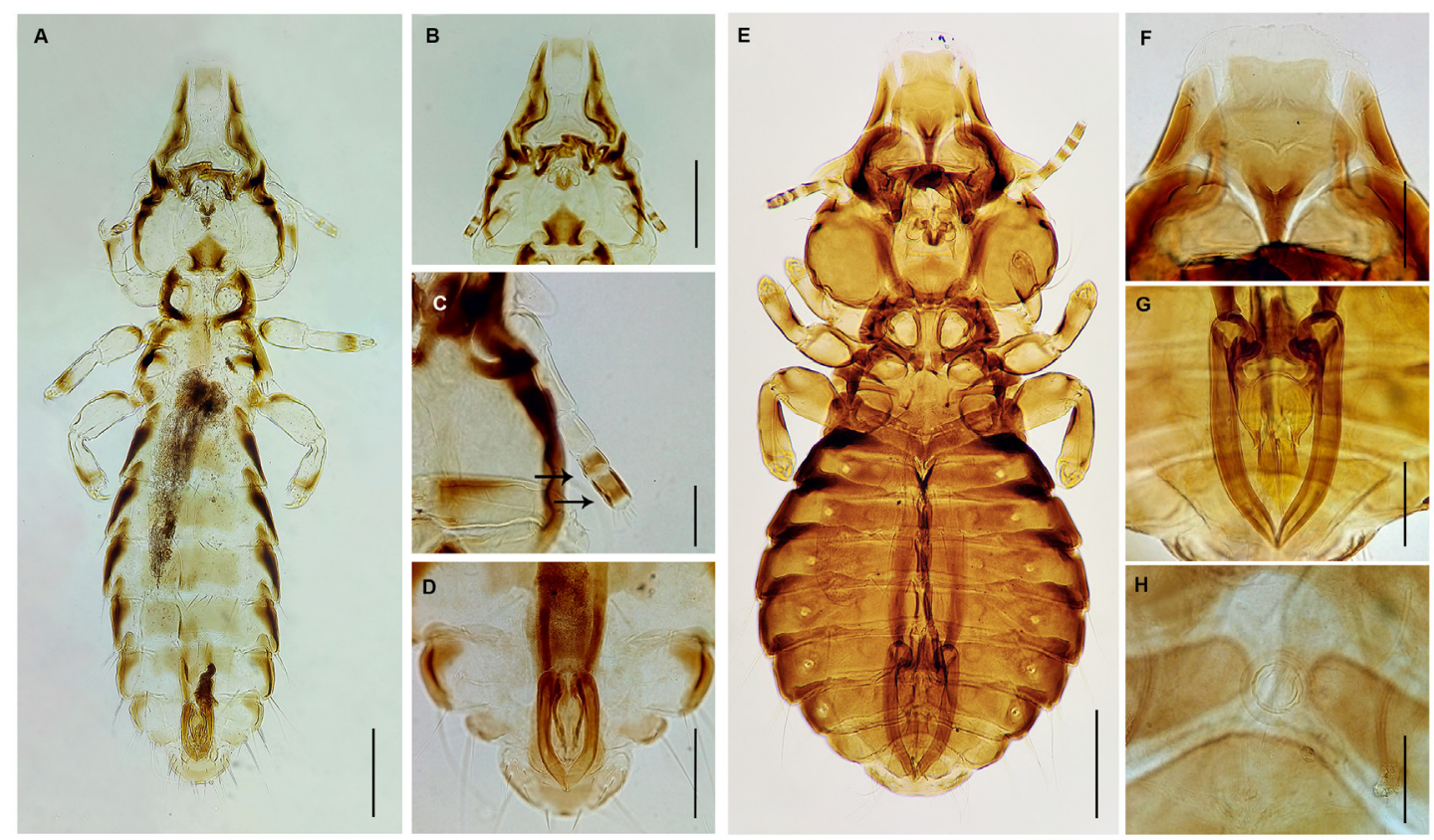

Fig. 5. A-D. Quadraceps eugrammicus, A. Whole body (male) $(200 \mu \mathrm{m})$, B. Dark coloration around the edge of the head $(200 \mu \mathrm{m})$, C. Last two segments of the antenna, presents dark coloration $(50 \mu \mathrm{m})$, D. Male reproductive system $(100 \mu \mathrm{m})$. E-H. Saemundssonia lari, E. Whole body (male), dorsal view $(200 \mu \mathrm{m})$. F. Triangular sclerite with dark coloration at the tip $(100 \mu \mathrm{m}), \mathrm{G}$. Male reproductive system $(100 \mu \mathrm{m}), \mathrm{H}$. Female genital pore $(50 \mu \mathrm{m})$.

Material studied: MUFV: ZOO-HPIA:160.

Host: Larus belcheri, Peru: Lima: Ventanilla, $11^{\circ} 52^{\prime} 15.352^{\prime \prime} \mathrm{S}, 77^{\circ} 9^{\prime} 30.283^{\prime \prime} \mathrm{W}, 21-23 . \mathrm{ix} .2017$, Naupay A.

Description: Based on 5 individuals ( 3 males, 2 females). It has a strong coloration throughout the body. Temples not very widened. The width of the head is equal to or slightly less than the length of the head. The posterior appendage of the clipeal dorsal plate clearly composed of two parts: a conical and colored part, followed by a lighter prolongation that ends in a sharp shape and with a dark coloration. Male: Total body length 1725 (1619-1817, $\mathrm{n}=3$ ); head length 579 (555-594), head width 593 (589-599); prothorax length 158 (140-171), pterothorax length 219 (200-246); abdomen length 813 (765-853), abdomen width 814 (805-820). Female: Total body length 2052 (2051-2052, $\mathrm{n}=2$ ); head length 629 (607-651), head width 659 (657-660); prothorax length 161 (158-163), pterothorax length 239 (216-262); abdomen length 1068 (1065-1071), abdomen width 1031 (1027-1034).

Comment: This species was recorded in Chile in hosts of the family Laridae by González-Acuña et al. (2006). In Peru it has been previously reported in Leucophaeus atricilla, from Atocongo,
Lima, and in Larus belcheri from Pisco, Ica (Dale, 1970). Additionally, Gomez-Puerta \& Cribillero (2015) reported S. lari in Larus pipixcan in the Province of Huaral, Lima. Therefore, the ectoparasite-host relationship found in this study coincides with what has already been reported.

\section{DISCUSSION}

Peru has a great diversity of birds, with approximately 1870 species (Plenge, 2020). However, the number of bird species evaluated for the study of chewing lice is still low (GomezPuerta \& Cribillero, 2015), despite the importance of these studies because of the effects of parasites like lice in birds. These parasites have direct pathological effects (hyperkeratosis and damage to feathers), and indirect effects such as negative sexual selection for parasitized birds (Lopez et al., 2008; Liebana et al., 2011; MorenoRueda \& Hoi, 2012).

Among the results of this investigation, we report the species $Q$. eugrammicus, $S$. lari and A. transversum parasitizing the Peruvian seagull Larus belcheri (Charadriiformes). These three species of lice have been recorded in birds of the Laridae family in Chile, the Galapagos Islands, and Mexico (Emerson, 1972; González-Acuña et 
al., 2006; Palma \& Peck, 2013), but only S. lari was previously reported in $L$. belcheri (Dale, 1970). Birds of the genus Larus are highly prone to the transmission of ectoparasites due to the close relationship between their species, sharing spaces in their habitat, nesting and feeding (Gómez \& González, 2010; Lenzi, 2011), which could generate contagion between species.

We also report two taxa of lice in the family Ricinidae, the genera Trochiloecetes and Ricinus, although both genera belong to the same family, they parasitize different orders of birds. In our study we report for the first-time T. illumani parasitizing T. leucurus. In the case of Ricinus frenatus, Valan et al. (2016) reported this species in association with different birds of the order Passerifomes. These results agree with the ones published by Soto-Patiño et al. (2018), who report the Ricinus genus in multiple Passerifomes birds.

Four species of ectoparasites were identified in the common pigeon Columba livia. This host bird has been studied in Brazil by Amaral et al. (2017) who reported the same species of ectoparasites in their study. In Peru, different authors have reported the same association of ectoparasites with the host, found in C. columbae (Naupay et al., 2015; Castro et al., 2017), C. turbiratum and C. compar (Dale, 1970), however, it was not previously reported for $H$. lata. The diversity of ectoparasites in C. livia could be attributed to the fact that this species has a close interaction with domestic and wild birds, in addition to being located in different parts of the city, which can generate a cross contagion (Begum \& Sehrin, 2011).

\section{CONCLUSION}

Our results show important contributions to the diversity of chewing lice in birds of Peru, including four new reports of lice for the country. Likewise, new associations were found, expanding the list of hosts for four species of chewing lice. This work highlights the need to investigate parasites in birds that do not present previous studies on ectoparasites since these birds are likely to harbor new species for Peru and science.

\section{BIBLIOGRAPHY}

Abrahamovich, A.H., M. Lucia, N.B. Díaz, M.F. Batiz \& D.D.C. Castro. 2006. Types of lice (Insecta, Phthiraptera) housed in the Museo de La Plata, Argentina. Zootaxa 1344(1): 43-58.

Adly, E., M. Nasser, D. Soliman, D.R. Gustafsson \& M.
Shehata. 2019. New records of chewing lice (Phthiraptera: Amblycera, Ischnocera) from Egyptian pigeons and doves (Columbiformes), with description of one new species. Acta tropica 190: 22-27.

Amaral, H.L., F.B. Bergmann, P.R.S. dos Santos, T. Silveira \& R.F. Krüger. 2017. How do seasonality and host traits influence the distribution patterns of parasites on juveniles and adults of Columba livia?. Acta tropica 176: 305-310.

Arnold, D.C. 2006. Review of the genus Acidoproctus (Phthiraptera: Ischnocera: Philopteridae), with description of a new species. Journal of the Kansas Entomological Society 79(3): 272-282.

Begum, A. \& S. Sehrin. 2011. Prevalence and seasonal variation of ectoparasite in pigeon, Columba livia (Gmelin, 1789) of Dhaka, Bangladesh. Bangladesh Journal of Zoology 39(2): 223-230.

Carriker, M.A., Jr. 1950. Some bird lice of the Genera Acidoproctus and Quadroceps (Neotropical Mallophaga Miscellany No. 3). Proceedings of the United States National Museum 100(3266): 377-386.

Carriker, M.A., Jr. 1960. Studies in Neotropical Mallophaga, XVII: a new family (Trochiliphagidae) and a new genus of the lice of hummingbirds. Proceedings of the United States National Museum 112: 321-329.

Castro, J., A. Naupay, K. Orozco, S. Rodríguez, Y. Díaz, J. Navarro \& N. Purca. 2017. Ectoparásitos de Columba livia Linnaeus, 1758 (Aves: Columbiformes) del distrito de Carmen de La Legua, Callao, Perú. The Biologist (Lima) 15(2): 425-435.

Clay, T. 1959. Key to the species of Austromenopon Bedford (Mallophaga) parasitic on the Charadriiformes. Proceedings of the Royal Entomological Society of London 28(11-12): 157-168.

Clayton, D.H., J.A. Koop, C.W. Harbison, B.R. Moyer \& S.E. Bush. 2010. How birds combat ectoparasites?. The Open Ornithology Journal 3(1): 41-71.

Cortés, J.A., V. Usbekc, J.J. Calderón \& G. Castillo. 2016. Comparación de los ectoparásitos presentes en Columba livia y Zenaida auriculata. Revista de la Asociación Colombiana de Ciencias Biológicas 1(28): 96-104.

Dale, W. 1970. Mallophaga (Hexapoda) en aves de la costa y sierra centrales de Perú. Tesis para optar el grado de Magister. Universidad Nacional Agraria La Molina, $201 \mathrm{pp}$.

De Oliveira, P.R., M.J.S. Mundim, D.D. Cabral, S.D.A. Ribeiro \& G.N. Rosa. 2000. A survey of parasitic fauna in domestic pigeons (Columba livia domestica) in Uberlândia, MG, Brazil. Veterinária Notícias 6(2): 53-56.

Eichler, W. 1953. Mallophagen-Synopsis. XXIV-Genus Penenirmus (incl. Picophilopterus). Zoologischer Anzeiger 150: 235-245.

Emerson, K.C. 1972. Checklist of the Mallophaga of North America (north of Mexico). Part II, suborder Amblycera. Deseret Test Center, Dugway Proving Ground, Dugway, Utah. 102 pp.

Ferreira, C.G.T., C. Mafra, A.C.D.S Bezerra, O.V. de Carvalho, A.S. Júnior \& M.R. de Almeida. 2013. Campanulotes compar (Burmeister, 1838) (Phthi- 
raptera: Ischnocera) in chickens (Gallus gallus domesticus) from Rio Grande do Norte State, Brazil. The reemergence of an ectoparasite?. Veterinary parasitology 195(1-2): 203-204.

Figueiredo, M.A., A.C.G. Santos \& R.D.M.S. Guerra. 2010. Ectoparasites of wild animals in Maranhão. Pesquisa Veterinária Brasileira 30(11): 988990.

Gómez, D.E. \& J. S. González. 2010. Trophic structure in a seabird host-parasite food web: Insights from stable isotope analyses. PLoS ONE 5(5): 1-10.

Gomez-Puerta, L.A., \& N.G. Cribillero. 2015. Contribución al conocimiento de los malófagos (Phthiraptera, Amblycera, Ischnocera) de aves peruanas: Parte 1. Revista Peruana de Biología 22(3): 341-346.

Gomez-Puerta, L.A. \& C. Luján-Vega. 2018. Contribución al conocimiento de los malófagos (Phthiraptera, Amblycera, Ischnocera) de aves del Perú. Parte 2. Revista Peruana de Biología 25(1): 35-42.

González, D., G. Castillo, J. López, L. Moreno, S. Donoso, O. Skewes, R. Martínez \& J. Cabello. 2004. Salud Animal: Parásitos gastrointestinales y externos de la paloma domestica (Columba livia) en la ciudad de Chillán, Chile. Agro-Ciencia 20(2): 107-112.

González-Acuña, D., C. Fischer, R. Palma, L. Moreno, C. Barrientos, L. Muñoz, K. Ardiles \& A. Cicchino. 2006. Piojos (Phthiraptera: Insecta) de aves de la familia Laridae (Aves: Charadriiformes) en Chile. Parasitología latinoamericana 61(3-4): 188-191.

Hasan, M. 2019. Detection of ectoparasites in different birds. Iraqi Journal of Veterinary Sciences 33(2): $37-41$.

Hicks, O., S.J. Burthe, F. Daunt, M. Newell, A. Butler, M. Ito, K. Sato \& J.A. Green. 2018. The energetic cost of parasitism in a wild population. Proceedings of the Royal Society B: Biological Sciences 285(1879): 20180489

Lenzi, J. 2011. Patrones de variación en las historias de vida de gaviotas (Larus spp.) en América.Tesis de Maestría. Universidad de la República, Montevideo, Uruguay. 50 pp.

Liebana, M.S., M.A. Santillan, A.C. Cicchino, J.H. Sarasola, P. Martinez, S. Cabezas, \& M.S. Bo. 2011. Ectoparasites in free-ranging American Kestrels in Argentina: implications for the transmission of viral diseases. Journal of Raptor Research 45: 335-341.

Lopez, G., J. Figuerola \& R. Soriguer. 2008. Carotenoid-based masks in the European Goldfinch Carduelis carduelis reflect different information in males and females. Ardea 96: 233-242.

Martín, M.P. 2006. Diversidad y distribución de las especies de Mallophaga (Insecta) en aves y mamíferos de la comunidad de Madrid. Graellsia 62: 21-32.

Martín, M.P. 2009. Fauna Ibérica. Vol 32 Phthiraptera, Ischnocera. $1^{\text {ra }}$ ed. Madrid: CSIC, Madrid. 368 pp.

McAllister, C.T., L.A. Durden, K.N. Brecheisen \& W.K. Reeves. 2018. New ectoparasite (Phthiraptera; Siphonaptera; Diptera) records from birds (Strigiformes: Passeriformes) and mammals (Lagomorpha; Rodentia) in Southeastern Oklahoma. Proceedings of the Oklahoma Academy of Science 98:
33-36.

Mey, E. 2004. Zur taxonomie, verbreitung und parasitophyletischer evidenz des Philopterus-komplexes (Insecta, Phthiraptera, Ischnocera). Ornithologischer Anzeiger 43(2): 149-203.

Moreno-Rueda, G. \& H. Hoi. 2012. Female house sparrows prefer big males with a large white wing bar and fewer feather holes caused by chewing lice. $\mathrm{Be}$ havioral Ecology 23: 271-277.

Naupay, A., J. Castro, J. Caro, L. Sevilla, J. Hermosilla, K. Larraín, C. Quispe \& O. Panana. 2015. Ectoparásitos en palomas Columba livia comercializadas en un mercado del distrito de San Martín de Porres, Lima, Perú. Revista de Investigaciones Veterinarias del Perú 26(2): 259-265.

Naz, S., O. Sychra \& S.A. Rizvi. 2012. New records and a new species of chewing lice (Phthiraptera, Amblycera, Ischnocera) found on Columbidae (Columbiformes) in Pakistan. ZooKeys 174: 79-93.

Nelson, B.C. 1972. A revision of the New world species of Ricinus (Mallophaga) occurring on Passeriformes (Aves). Berkeley, University of California Publications Entomology, $175 \mathrm{pp}$.

Palma, R.L. 1978. Slide-mounting of lice: a detailed description of the Canada balsam technique. New Zealand Entomologist 6(4): 432-436.

Palma, R.L. \& S.B. Peck. 2013. An annotated checklist of parasitic lice (Insecta: Phthiraptera) from the Galápagos Islands. Zootaxa 3627(1):1-87.

Parra-Henao, G., E.P. Alarcón-Pineda, G. López-Valencia, D.M. Ramírez-Monroy \& G.E. Jaramillo-Crespo. 2011. Detection of ectoparasites in wild birds evaluated in Medellin (Colombia). Revista Colombiana de Ciencias Pecuarias 24(1): 29-37.

Pérez, J.G., D.A. Monsalve \& C. Márquez. 2015. Presencia de parásitos y enterobacterias en palomas ferales (Columba livia) en áreas urbanas en Envigado, Colombia. Revista Facultad Nacional de Salud Pública 33(3): 370-376.

Plenge, M. A. 2020. List of the birds of Peru. Boletín. Unión de Ornitólogos del Perú: https://sites.google. com/site/boletinunop/checklist , accessed on: 05-052020

Price, R. D., R.A. Hellenthal \& R. L. Palma. 2003. World checklist of chewing lice with host associations and keys to families and genera. The chewing lice: world checklist and biological overview. Illinois Natural History Survey Special Publication 24:1-448.

Quiguango V.D.M. 2015. Determinación de la presencia de parásitos externos en palomas de castilla (Columba livia) en la ciudad de Quito, tomando como referencia tres lugares pilotos "La Magdalena","Plaza de San Francisco" y "Cotocollao. Tesis de pregrado. Universidad Central de Ecuador. Quito- Ecuador. 56 pp.

Roda, S.A. \& Â.M.I.D. Farias. 1999. Wild birds infested by Phthiraptera (Insecta) in Pernambuco North Zona da Mata. Revista Brasileira de Zoologia 16(3): 871-878.

Saavedra-Orjuela, A., Arévalo-Barreto, S. \& D. SolerTovar. 2014. Ectoparásitos del orden Phthiraptera 
en aves silvestres. Memorias de la Conferencia Interna en Medicina y Aprovechamiento de la Fauna Silvestre, Exótica y no Convencional 10(2): 5-24.

Schulenberg, T., Stotz, D., Lane, D., O’Neill, J., Parker III, T., 2010. Birds of Peru. Versión en español. Serie biodiversidad CORBIDI. 410 pp.

Smith, V.S., Y. Broom \& R. Dalgleish. 2020. Phthiraptera.info. http://phthiraptera.info/ Accessed on 2504-2020.

Soto-Patiño, J., G.A. Londoño, K.P. Johnson, J.D. Weckstein, J.E. Avendaño, T.A. Catanach, A.D. Sweet, A.T. Cook, J.E. Jankowski \& J. Allen. 2018. Composition and distribution of lice (Insecta: Phthiraptera) on Colombian and Peruvian birds: New data on louse-host association in the Neotropics. Biodiversity data journal 6: e21635.

Tavera, E. A., D. Minaya, E.O. Lopez, J. Iannacone \&
D.B. Lank. 2019. Chewing lice richness and occurrence in non-breeding shorebirds in Paracas, Perú. Wader Study 126(3): 190-199.

Timmermann, G. 1952. XXIII.-The species of the genus Quadraceps (Mallophaga) from the Larinae. With some remarks on the systematics and the phylogeny of the gulls. Annals and magazine of Natural History 5(51): 209-222.

Valan, M., O. Sychra \& I. Literak. 2016. Chewing lice of genus Ricinus (Phthiraptera, Ricinidae) deposited at the Zoological Institute of the Russian Academy of Sciences, Saint Petersburg, Russia, with description of a new species. Parasite 23: Art. 7, 10 pp..

Valim, M.P. \& P.M. Linardi. 2007. Description of the male of Mayriphilopterus nystalicus Mey, 2004 (Phthiraptera, Ischnocera, Philopteridae). Zootaxa 1604(1): 47-51.

Doi: 10.22179/REVMACN.22.697

Recibido: 19-VII-2020

Aceptado: 23-X-2020 
